\title{
The Challenges While Measuring Enterprise Innovative Activities - the Case from a Developing Country
}

\author{
Indira POPADIĆ, Jelena BOROCKI, Mladen RADIŠIĆ, Ivan ŠTEFANIĆ, Lena DUSPARA
}

\begin{abstract}
Small and medium-sized enterprises (SME sector) carry a significant component of an overall economy performance in both developed and developing countries. This paper presents the results of innovation activities analysis on a given sample of SMEs from the Republic of Serbia. By implementing a complex questionnaire for assessing innovation activities authors investigate what innovation activities are conducted in sampled enterprises. Results are processed with Cochran Q, McNemar and statistical significance tests and indicate what particular innovation activities measures enterprises focus on, as well as what measures are considered as relevant by enterprises but are not used. At the same time, the factor analysis was performed to test the quality and structure of the questionnaire itself, namely whether measures of achieved innovation performances of enterprises are properly divided into categories. Additionally, specific innovation activities were analyzed and their implementation modalities by the sampled enterprises. The results contribute in the domain of better understanding of innovation activities measurement within SMEs coming from developing countries. Based on the research results, we got the insight into specific innovation activities SMEs perform, as well as key innovation performance indicators SMEs use.
\end{abstract}

Keywords: Cochran Q test; developing countries; innovation activities; McNemar test; small and medium enterprises

\section{INTRODUCTION}

Numerous specifics accompany small and medium enterprises (SMEs) in the developing countries such as recent change from centralized towards market economy, lack of staff experience and competencies for challenging overall economy aspect, a number of micro enterprises with only one employee, unstable external environment of quick changes, and some others. However, their importance for the economy of such countries is very similar to the importance of SMEs in developed countries. Additionally, they should be the holders of structural changes in the developing countries [1]. Changes impacting enterprises also affect developed states and transitional states, but the speed of response as well as consequences resulting from changes are not the same. In recent years, developing countries have, to a high extent, modified their innovation systems, participated in officially selected systems of state innovation measurement, and aimed at stimulating the development of innovative enterprises using different methods. Institutional support is necessary not only as the one of the prerequisites of initiating entrepreneurial ventures, but also as a condition of raising awareness about the significance of innovation for competition of both state and privately owned enterprises. Innovation support from the state is very important in such conditions, irrespective of support form which is present: supporting venture capital funds for the purpose of improving conditions of operations, ensuring technical and managerial educated staff in the area of innovation, ensuring infrastructure, and numerous other activities of public-private partnership [2].

Innovation generated using sophisticated technologies as well as any other innovations and globalization as social phenomenon, have significantly modified SME operating conditions. They increasingly take high requirements of informed customers into consideration, and become more aggressive and ingenious, more flexible and faster in their aim to conquer new markets and keep the existing ones. In case of developing countries, number of innovative enterprises is very modest. The reason is most often that SMEs lack sufficient funds for the implementation of innovative activities and lack the availability of methodologies for the evaluation of innovative activities; they lack quality staff with appropriate level of knowledge in a field; equipment and technology used may be obsolete; lack of public-private partnerships, research and development centres, etc. In addition, SMEs in developing countries are facing not so good conditions to measure innovative activities and introduce the systems of their controlling and managing in this respect. With regard to the frequency of implementation, SMEs very infrequently or not at all, measure performances of enterprise innovation.

Nowadays, innovations, irrespective of innovation category, independently of the degree of novelty built in an innovative offer, are a basis of enterprise competitiveness. This claim is widely applicable, irrespective of economic branch, activity, ownership structure, or enterprise size [37]. Since SMEs account for more than $90 \%$ of the total number of enterprises of a state, the impact of competitiveness of a state may not be neglected. State innovation measurement is ensured in standardized reports [8] (Eurostat http://ec.europa.eu/eurostat; the European Commission; Innovation Union Scoreboard - IUS; European Innovation Scoreboard - EIS; etc.). Regarding enterprise innovative activity measurement, situation is somewhat more complex. A performance of company innovative activity measurement, i.e. performance measurement system is a basis for enterprise competitiveness acquiring and measuring. Since SMEs express certain problems in the application of the performance system, as stated in Garengo et al. [9]: lack of holistic approach; informal system which is not applied in a planned manner; restriction of resources of measuring and interpreting of obtained results; lack of adopted model or incorrect use of measurement model, etc., it may be assumed that, in the event of the application of company innovative activity measurement, such situation will be similar.

Innovation may be expressed not only through product/service innovations, but also in terms of process, market, organization, and/or business model innovation. Numerous researches dealing with the evaluation of innovative capability of small and medium enterprises 
have strived to answer which innovation aspect is characteristic for SMEs [10, 11]. In innovation application, technology is very important, equally important as the method of implementing company business activities for which highly sophisticated technologies are not necessary to be used: creative problem solving, product design, new method of organization and process implementation, etc. SMEs in developing countries face a lack of financing to be used for the improvement of companies' innovative capabilities. In this respect, there is a higher probability that innovation will be based on services and/or aspects which do not require the state-of-the-art technology or equipment following such technology, as well as significant financial resources. In terms of company innovative activity measurement and definition of a set of performances, the problem is lack of single methodology and set of performances (which is frequently case regarding companies from developed countries). In developing countries, such situation is even more complex. Some researches show that innovation performance of firms strongly depends on the synergies and external linkages in the local environment. In such conditions, policy support is important in encouraging innovative enterprises and thus achieving better economic performance in the form of higher sales growth [12].

The aim of this paper is to present current situation in the Republic of Serbia regarding performance measures of innovative activities in domestic SMEs. The presented research challenges the applicability of designed questionnaire to the SMEs in Serbia.

\section{THEORETICAL BACKGROUND}

Nowadays, SMEs face the problems of restricted funds, lack of adequately educated staff, lack of state-ofthe-art production equipment, simultaneous implementation of multiple heterogeneous activities by staff, etc. As argued by Schwab [13], in developing countries, there is often a high unemployment rate, low level of state competitiveness and innovation, including the issues of corruption and lack of investments, noncompliance of legal and other systems with the legal systems of developed countries. It hampers the implementation of business activities, therefore SME face the problems which are not typical to developed countries. High level of external environment instability is often defined with completely different set of factors than in developed countries. The overall context in which innovation in developing countries takes place is dominated by two global drivers. The first one is the intensification of the globalization process and the second one is the intensive ongoing technological change stimulated by tremendous scientific advances made in the foundations of life, matter, energy and time [14]. According to Hobday [15], in developing countries enterprises frequently operate within small, underdeveloped markets and the innovation infrastructure (including educational institutions and human resources) may well be lacking. He also claims that technology has to be transferred and absorbed from foreign sources for catch up innovation to take place. Because of lack of resources, small enterprises are often unable to innovate and thus they have a low survival rate [16]. Specifically, the relation between a firm size and innovation has been continuously explored in literature [17]. As Zacarías and Arjona state [18], the association capability can leverage the innovation related to the new product development, if the SME is characterized as entrepreneurial, flexible, and adaptive to the environment.

In terms of innovation, SME may opt for an attempt of individual implementation of innovation, through own research and development centres and particular innovation management techniques. On the other hand, they may acquire innovation ideas through cooperation with other companies, formal institutions (faculties, development agencies, external research and development centres), customers/clients, and other relevant partners. Clustering or other forms of organization may, to a certain extent, support SMEs to improve their innovation activities. Though innovation significance awareness is high at majority of companies, a system for innovation activity measurement is rarely used or is non-existent. Particular innovation types do not have any direct impact to company performances, and it is very difficult to define them in an official system. Sometimes, it also takes much time for first results to appear. All this is not the reason that company innovation activities are not to be measured, especially with regard to the fact that a number of researchers, indeed, claim that innovative activities have a positive impact to other company performances [19-22].

Innovative small and medium-sized enterprises make a significant contribution in the global economy with respect to enterprise development and new job creation. There also is an increasingly important role for SMEs to contribute to economic growth and technological development specifically in those developing countries where liberalization and globalization of the economy is currently taking place. The heterogeneous nature of SMEs on one hand and their behavioural advantages on the other, enable them to be innovative. Research supports the notion that SMEs that are engaged in innovation activities are better performers [23-26].

Innovation, uncertainty and evolution are the main aspects of diversity between SMEs and large companies $[27,28]$. In order to solve these problems, SMEs should have performance measurement system: thus they will manage uncertainty, innovate their products/services and sustain evolution and change processes. Some other researchers think that (taking into consideration the nature of SMEs) there is no need to have a formalized system in SMEs, since the problems are more visible, networks are less complex and the main processes are faster repaired than in large companies [9].

Improvement of organizational performances, in the conditions of markets and economies uniting, represents the primary objective of every successful organization with the aim of improving competition and financial stability. Development and investment into innovativeness and implementation of a system approach in this sense is by all means a prerequisite for development of organisational performances, a prerequisite for competitiveness and survival at the market [29]. In their study Chennell et al. [30] affirmed that the basic obstacles for implementation of performance measurement in SMEs could be defined as 
'exogenous' barriers, e.g. the lack of financial and human resources, and 'endogenous' barriers, e.g. short-term strategic planning and the perception that performance measurement system is bureaucratic.

Based on innovative activity classification [8, 31, 32] according to which they may be classified into the following groups: a) Internal research and development (IR); b) External research and development services; c) Procurement of new machines, equipment, and software; d) Purchase of other forms of knowledge as well as procurement of non-installed technology; e) Internal and external staff education and training; f) Introduction of innovation to market, and g) Design change, it is clear that innovative activities include all scientific, technological, organizational, financial, and commercial steps, resulting in or intended for innovation implementation. Companies active in innovation are all of the companies which have, within the respective period, implemented a type of innovation: they have introduced a new service, product, process, or have implemented an innovation in their marketing or organization. The essential point is that innovation activities may not be observed independently of some other company activities.

Actual performance of company's innovation activities, which is measured by the innovation output indicators, is a good base for defining the organizational innovativeness [33]. As Sepúlveda and Vasquez [34] claim, measuring innovation is only the initial step in the search of better performance in this management domain of an organization. A single path or recipe for success in innovation does not exist, but it is possible for each company to find where the increased efforts must be focused in order to transform a specific success in a process of continuous innovation. In this respect the main research question we imposed was related to the following: is there a structured way of SMEs innovation performance indicators measurement? In addition, it was interesting to understand whether such indicators could be clustered in a certain way.

\section{RESEARCH METHOD}

With regard to the Republic of Serbia as a developing country, entrepreneurial climate in its environment as well as the necessary basis for starting up SMEs, have only recently become dynamic. The situation indicates that the majority of companies are started up due to necessity ("a must"), and, in a lesser number of cases, those are entrepreneurial ventures followed by innovative solutions. A high number of newly established companies are from the service sector - production of innovative products is more complex in conditions of unstable environment and modest development funds. Thanks to the support of governmental institutions, participation in European projects through which particular funds are provided, cheap labour force, quality staff, and relatively modest funds necessary for starting up and maintaining company business within the ICT sector, these problems are, to some extent, overcome. Operation intensity, product quality, number of production companies using high technology have significantly been reduced in recent years. A number of companies have managed to keep their activity thanks to their cooperation with other companies from their environment, changing their ownership structure, and decreasing activity volume and intensity. Continuing changes condition all companies to find different solutions, be innovative if they want to survive and further develop themselves. Even though they have particular export facilities, SMEs in the Republic of Serbia have particular difficulties in product export, above all, because they may not respond to high requirements of the European/world markets, accordingly they become non-competitive.

The starting point in the implementation of the empirical research was the official questionnaire of the Statistical Office of the Republic of Serbia [35] based on the Eurostat methodology, which was modified and supplemented with particular segments which should have contributed to new information on the innovative capabilities of the SME sector. This official methodology focuses on regional innovation comparison rather than on in-depth innovation performance indicators analysis. The underlying rationale for implementing such an approach is obtaining overall national information that will support states innovation policies. The main reason for this questionnaire extension was the need for proper determination of innovation performance indicators that SMEs use and consider as the most relevant for their business. Although SMEs do not implement all performance indicators they consider relevant, such an approach was a good starting point for understanding innovation performance indicators application in SMEs in developing countries. Our questionnaire was enriched with questions about specific innovation performance indicators that are considered [36-40] as most widely applied integral parts of innovation measurement methodologies. The statistical processing of the obtained data covered the particular methods of the descriptive and comparative analysis. The following statistical procedures of data processing were applied: descriptive statistics for the description of the sample on tested variables: arithmetic mean, standard deviation, median, modus, minimum and maximum for numerical and ordinal variables, and percentages for categorical variables; Chi-square test, Cochran's Q test [41]. The objects of the research were chosen by applying a random sampling.

In this survey, 159 companies from Serbia have participated, both manufacturing and service companies. Most of them are small companies (52,2\%), 34\% are medium size, while $13,2 \%$ of them are large companies. In terms of origin of the majority of the capital, the domestic capital dominates with $84,3 \%$, over foreign capital $(11,3 \%) .76,1 \%$ companies from the research sample are organized as limited liability companies [41].

The questionnaire used in this research consists of several parts: I) general information about business entity, II) relations with respect to innovation - identification of innovation types and innovative activities at a company, IIIa) financial aspects - investment in the innovative activities and effects of such investments, III b) evaluation of presence of measures of achieved innovative performances of companies from the aspect of using measurements at company. The questionnaires were filled in direct contact with company director or managers of the development sector. In the IIIb, a five-point Likert scale was used in order to assess the level of impact of selected factors on innovation capability of the company. When 
modifying the questionnaire, our intention was to cover the missing aspects of the officially used questionnaire with some new elements, such as identification of a potential set of critical measures for company's innovative activity measurement, expansion of innovation type set, information sources - innovation activity holders, etc. The questionnaire structure and content are also aligned with the theoretical postulates of numerous authors who have, in their researches, studied not only product innovations, but also the time necessary for innovation to be placed on the market, novelty degree, etc. [42-44].

In the last part of the questionnaire (Part IIIb) the measures that companies evaluated, were divided into four groups that correspond to the four groups/four basic dimensions of the Balanced Scorecard model: customer relationships, learning and development of employees, finances and internal processes. Factor analysis was used to check whether or not four aspects of the organization's performance observation are identified, as well as examination of the quality of the findings themselves in order to enhance the questionnaire for gathering factor data affecting the innovative performance of the organization in further research.

\section{RESULTS AND DISCUSSION}

In this section we present results of the selected questions from our methodological approach. The main criteria for presenting exactly those analyzed results is the fact that they contribute mostly in our intention to enrich the official national questionnaire. They give us exact insight into innovation activities modalities and types within SMEs. Under the assumption that respondents have introduced a product/service innovation in their operation, we were interested in the novelty degree, i.e. whether respective products/services are new on the market or whether they are new only to their company. The results are given in section 4.1 and the discussion is presented in section 4.2 .

\subsection{Performed Statistical Significance Tests}

Collected data were tested with the help of Cochran's $\mathrm{Q}$ test and McNemar's tests. Cochran's Q tests the null hypothesis that the proportion of "successes" is the same in all groups versus the alternative that the proportion is different in at least one of the groups. Cochran's Q test is an extension of the McNemar's test to a situation where there are more than two matched samples. Cochran's Q is also considered to be a special case of the non-parametric Friedman test, which is similar to repeated measures ANOVA and is used to detect differences in multiple matched sets with numeric responses [45].

The highest number of investigated companies affirmatively answered that they have introduced product/service innovation, but it was a novelty only to their company, not to the market they operate on.

Among the questions there was one describing operating process of innovation. The respondents were expected to affirmatively or negatively answer the following statements relating to degree of process novelty: (a) new or significantly improved product/service production method, (b) new or significantly improved method of appearance on the market, and (c) new or significantly improved logistic activity management. The results are presented in Tab. 2.

Table 1 Degree of novelty in terms of product/service innovation

\begin{tabular}{|l|c|c|c|c|}
\hline \multicolumn{3}{|c|}{ Frequency } \\
\hline \multicolumn{2}{|c|}{} & \multicolumn{2}{|c|}{$\begin{array}{c}\text { New to the } \\
\text { enterprises }\end{array}$} & \multirow{2}{*}{ Total } \\
\cline { 3 - 5 } \multicolumn{2}{|c|}{} & No & Yes & \\
\hline \multirow{2}{*}{ New product/service at the market } & No & 6 & 36 & 42 \\
\cline { 3 - 5 } & Yes & 18 & 13 & 31 \\
\hline Total & 24 & 49 & 73 \\
\hline \multicolumn{3}{|c|}{ Chi-square test } \\
\hline McNemar Test & Value & \multicolumn{3}{c|}{ Significance } \\
\hline No of cases & - & \multicolumn{3}{c|}{0.020} \\
\hline
\end{tabular}

Table 2 Process innovations

\begin{tabular}{|l|c|c|}
\hline \multicolumn{2}{|c|}{ Frequencies } & \multicolumn{2}{|c|}{ Value } \\
\cline { 2 - 3 } & 0 & 1 \\
\hline $\begin{array}{l}\text { New or significantly improved product/service production } \\
\text { method }\end{array}$ & 37 & 64 \\
\hline $\begin{array}{l}\text { New or significantly improved method of launching on the } \\
\text { market }\end{array}$ & 59 & 42 \\
\hline New or significantly improved logistic activity management & 67 & 34 \\
\hline \multicolumn{2}{|c|}{ Statistics } & 101 \\
\hline$N$ & 27.321 \\
\hline Cochran's Q & 2 \\
\hline Number of degrees of freedom & 0.000 \\
\hline Significance & 2 \\
\hline
\end{tabular}

The results indicate that the highest number of investigated companies introduced operating process innovation, and it was done in such manner that they set up a new or significantly improved product/service production method. The highest number of them negatively answered the statement that the process of innovation at their company included new or significantly improved logistic activity management.

In terms of the activities introduced at company in the previous period, the results are presented in Tab. 3 .

Table 3 Specific activities introduced by company

\begin{tabular}{|c|c|c|}
\hline \multicolumn{3}{|l|}{ Frequencies } \\
\hline & \multicolumn{2}{|c|}{ Value } \\
\hline & 0 & 1 \\
\hline New approach in marketing researches & 121 & 30 \\
\hline New method of market performance & 94 & 57 \\
\hline New approach in customer relations management & 83 & 68 \\
\hline $\begin{array}{l}\text { Significant changes in design and packaging of existing } \\
\text { products }\end{array}$ & 95 & 56 \\
\hline New pricing methods & 121 & 30 \\
\hline New or significantly modified marketing channels & 112 & 39 \\
\hline New forms of market communication & 81 & 70 \\
\hline \multicolumn{3}{|l|}{$\begin{array}{ll}\text { Test Statistics } \\
\end{array}$} \\
\hline$N$ & \multicolumn{2}{|c|}{151} \\
\hline Cochran's Q & \multicolumn{2}{|c|}{53.743} \\
\hline Number of degrees of freedom & \multicolumn{2}{|c|}{6} \\
\hline Significance & \multicolumn{2}{|c|}{0.000} \\
\hline
\end{tabular}

The highest number of investigated companies confirmed that they introduced activities such as: new forms of market communication, new approaches in customer relations management, and new methods of market performance, respectively. The least number selected the activities such as: new approaches in marketing researches, new pricing methods, and new or significantly modified marketing channels.

The questionnaire included several questions where 
the respondents could give more than one answer and we classified them as multiple questions. Among them, those which could not be transformed and adjusted, were processed using the Cochrane test, and the subsequent comparisons were made using McNemar's test. The respondents who participated in the research were asked the question which entities they cooperated with the most. The results are presented in Tab. 4.

Table 4 Cooperation with other entities on the market

\begin{tabular}{|l|c|c|}
\hline \multicolumn{2}{|c|}{ Frequencies } & \multicolumn{2}{|c|}{ Values } \\
\cline { 2 - 3 } & 0 & 1 \\
\hline Faculty & 108 & 47 \\
\hline Development agencies & 132 & 23 \\
\hline Chamber of Commerce & 106 & 49 \\
\hline Other companies Statistics & 25 & 130 \\
\hline \multicolumn{2}{|c|}{} \\
\hline Number of respondents & 155 \\
\hline Cochran's Q & 165.189 \\
\hline Number of degrees of freedom & 3 \\
\hline Significance & 2.00 \\
\hline
\end{tabular}

It is seen in the table that there are differences in positions/frequencies and they are significant $(p=0.000)$. In addition, the highest number of the respondents answered that they cooperated with other companies, followed by the Chambers of Commerce and faculties. The least of them cooperated with Development Agencies, and almost no one selected other. When determining who innovation was developed by, the companies from the research sample responded as follows (Tab. 5).

Table 5 Cooperation of companies in terms of innovation development

\begin{tabular}{|c|c|c|}
\hline \multicolumn{3}{|l|}{ Frequencies } \\
\hline & \multicolumn{2}{|c|}{ Value } \\
\hline & 0 & 1 \\
\hline Individual company & 66 & 90 \\
\hline $\begin{array}{l}\text { Company, in cooperation with other organisations and } \\
\text { institutions }\end{array}$ & 105 & 51 \\
\hline $\begin{array}{l}\text { Company, based on the modification and adjustment of } \\
\text { products/services Developed by organisations and } \\
\text { institutions }\end{array}$ & 138 & 18 \\
\hline Other organisations and institutions & 154 & 2 \\
\hline \multicolumn{3}{|l|}{ Test Statistics } \\
\hline$N$ & \multicolumn{2}{|c|}{156} \\
\hline Cochran's Q & \multicolumn{2}{|c|}{116.386} \\
\hline Number of degrees of freedom & \multicolumn{2}{|c|}{3} \\
\hline Significance & \multicolumn{2}{|c|}{0.000} \\
\hline
\end{tabular}

Differences in positions/frequencies exist and are significant $(p=0.000)$. There is the highest number of the answers indicating that the companies individually developed innovations, excluding the participation of other organisations and institutions. The lowest number of the respondents, besides other options, encircled the answer "Other organisations and institutions".

The Factor analysis was used to determine the structure of the questionnaire designed to collect data on innovative business activities in Serbia. One of the assumptions in applying factor analysis is that sufficient data correlation is provided in the data matrix. The correlation between the variables and the justification for the application of factor analysis can be determined by two tests: Bartlett's sphericality test $(p<0.05)$ and Kaiser Meyer - Olkin 's sample adequacy indicator. Since the Kaiser - Meyer - Olkin's measure was satisfactorily high (0.867), and Bartlett 's spherical test had significant C2
$(1176, N=128)=4640.714 ; p=0.000)$ factor analysis was applied. Based on the Scree test and the interpretability of the obtained components, three components were retained, which accounted for $47.892 \%$ of variance. The hypothesis of the need to categorize measures which companies are using to evaluate innovative activities in four groups (dimensions) that match the core basic dimensions of the Balanced Scorecard model (customer relationships, learning and employee development, finance and internal processes) has not been confirmed.

Each of the separate factors needs to be named or tagged. Changes with higher loads are considered more important and have a greater impact on the name or mark selected to represent the factor. Factor 1 is named the Financial Performance of a Business because it is best defined by the variable such as: growth rate of return, return on invested assets, percentage of new product / service sales, revenue growth rate, gross margin percentage of new products/services, respectively. By the same criterion, and shown in Tab. 6, Factor 2 was named Organizational Performance of Enterprises and Factor 3 of Innovative Company Performance. Given that the identified changes that do not load on either factor, they should be eliminated from further analysis. Tab. 6 shows the correlations between the obtained factors.

Table 6 Extracted Factors Correlation Matrix

\begin{tabular}{|l|c|c|c|}
\hline \multicolumn{1}{|c|}{ Factor } & 1 & 2 & 3 \\
\hline 1 Financial performances & 1.000 & 0.586 & 0.476 \\
\hline 2 Organizational performances & 0.586 & 1.000 & 0.524 \\
\hline 3 Innovative performances & 0.476 & 0.524 & 1.000 \\
\hline
\end{tabular}

It can be noted that the greatest correlation is between Financial Performance and Organizational Performance factors $(r=0.586)$, then Organizational Performance and Innovative Performance $(r=0.524)$ and at the end of Financial Performance and Innovative Performance $(r=$ 0.476). The internal consistency of the scale was verified by calculating Cronbach's reliability coefficient. The lowest confidence coefficient has a factor encompassing innovative business performance $(\alpha=0.838)$, slightly higher has a factor that includes Organizational Performance $(\alpha=0.896)$, and the highest coefficient has a Financial Performance $(\alpha=0.942)$.

The analysis of the three factors was made by analyzing the difference and it is shown in Tab. 7.

Table 7 Differences between factors

\begin{tabular}{|c|c|c|c|c|c|c|}
\hline & 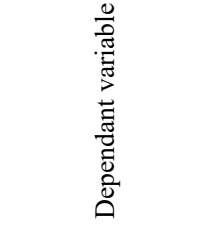 & 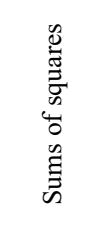 & 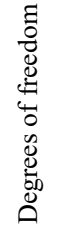 & 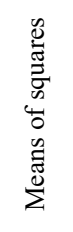 & $\underset{\omega}{\stackrel{\vec{\omega}}{\Phi}}$ & 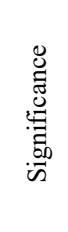 \\
\hline \multirow{3}{*}{ Contrast } & Finance & 10.484 & 3 & 3.495 & 3.719 & 0.013 \\
\hline & Org. performance & 0.927 & 3 & 0.309 & 0.304 & 0.822 \\
\hline & Inn. performance & 4.704 & 3 & 1.568 & 1.590 & 0.195 \\
\hline \multirow{3}{*}{ Error } & Finance & 116.516 & 124 & 0.940 & & \\
\hline & Org. performance & 126.073 & 124 & 1.017 & & \\
\hline & Inn. performance & 122.296 & 124 & 0.986 & & \\
\hline
\end{tabular}

In the last section of applied modified questionnaire the respondents ranked innovation performance indicators measures considered as relevant for their business. This 
provided information about the basic integral elements that need to be embedded of a potential model for innovation measurement in enterprises. The results are presented in Tab. 8 .

Table 8 Ranked frequencies of innovation performance indicators measures Usage frequencies of innovation performance indicators measures

\begin{tabular}{|c|c|c|c|}
\hline \multicolumn{2}{|l|}{ Relevant and used } & \multicolumn{2}{|l|}{ Relevant and not used } \\
\hline Indicator title & $(\%)$ & Indicator title & $(\%)$ \\
\hline Income growth rate & 78.99 & $\begin{array}{l}\text { Number of hours spent by } \\
\text { staff in activities of learning } \\
\text { about innovation and } \\
\text { innovation management }\end{array}$ & 38.36 \\
\hline $\begin{array}{l}\text { Level of customer's } \\
\text { satisfaction with the } \\
\text { characteristics of the new } \\
\text { product/ service }\end{array}$ & 66.04 & $\begin{array}{l}\text { Number of hours spent by } \\
\text { staff in activities of research } \\
\text { and development }\end{array}$ & 32.70 \\
\hline $\begin{array}{l}\text { Deadlines of responses to } \\
\text { customer requirements }\end{array}$ & 61.65 & $\begin{array}{l}\text { Time necessary for new } \\
\text { product/service launching } \\
\text { on market }\end{array}$ & 31.45 \\
\hline Employee productivity & 58.86 & $\begin{array}{l}\text { Number of hours spent by } \\
\text { staff in activities of } \\
\text { improvement of the existing } \\
\text { knowledge }\end{array}$ & 30.82 \\
\hline $\begin{array}{l}\text { No of new } \\
\text { products/services } \\
\text { introduced in previous } \\
\text { period }\end{array}$ & 57.23 & $\begin{array}{l}\text { Costs reduction based on } \\
\text { selling new } \\
\text { products/services to already } \\
\text { established clients }\end{array}$ & 29.56 \\
\hline $\begin{array}{l}\text { Available technological } \\
\text { knowledge (know-how) } \\
\text { of employees }\end{array}$ & 55.35 & $\begin{array}{l}\text { Number of seminars, } \\
\text { courses, trainings available } \\
\text { to staff }\end{array}$ & 28.93 \\
\hline $\begin{array}{l}\text { Growth rate (increase in } \\
\text { number) of new } \\
\text { customers }\end{array}$ & 55.35 & $\begin{array}{l}\text { Costs of service } \\
\text { provisioning to clients }\end{array}$ & 28.93 \\
\hline $\begin{array}{l}\text { The number of key } \\
\text { customer orders increase }\end{array}$ & 54.72 & $\begin{array}{l}\text { Return on investments in } \\
\text { new product/service } \\
\text { development }\end{array}$ & 28.30 \\
\hline $\begin{array}{l}\text { Level of employee's } \\
\text { satisfaction }\end{array}$ & 52.83 & $\begin{array}{l}\text { Time necessary to generate } \\
\text { profit from the new } \\
\text { product/service }\end{array}$ & 28.30 \\
\hline $\begin{array}{l}\text { Customer Loyalty } \\
\text { (Number of Repeated } \\
\text { Orders) }\end{array}$ & 52.83 & $\begin{array}{l}\text { Cost saving percentage as } \\
\text { result of new } \\
\text { product/service } \\
\text { development }\end{array}$ & 27.67 \\
\hline
\end{tabular}

\subsection{Discussion}

Research results indicate that the highest number of companies introduced operating process innovation, and it was done in such manner that they set up a new or significantly improved product/service production method.

In terms of the activities introduced at company in the previous period, it is noticed that most of the companies introduced innovative activities which do not have high requirements regarding significant amount of money. Further analysis of the observed differences among the frequencies, resulted in the following conclusions: (a) the respondents who did not introduce new approaches in their marketing researches mostly did not introduce new approaches in customer relations management (CRM), significant changes in design and packaging of existing products, or new forms of market communication; (b) a high number of the respondents did not introduce new pricing methods, they did not introduce new methods of market performance, or new approaches in customer relations management; (c) the respondents which did not introduce new or significant changes in design and packaging of existing products, and (d) the respondents which did not introduce new forms of market communication, to the highest extent, did not also introduce new or significantly modified marketing channels.

Regarding the cooperation with other entities at the market, it is noticeable that most of the companies from the research sample cooperate with other companies. This indicates that the climate of mistrust is still present. In further analysis, the following conclusions were drawn: (a) the respondents which did not cooperate with faculty mostly did not cooperate with development agencies; (b) the respondents which encircled answer other companies, mostly did not encircle cooperation with faculty as an additional option; (c) among the respondents, there is the highest number of those which, if they did not cooperate with development agencies, did not cooperate with the Chamber of Commerce either; (d) there is the highest number of those respondents which, if they confirmed cooperation with other companies, did not encircle the option of development agency, and (e) when the answers between Other Companies and Chamber of Commerce are correlated, it is concluded that there is the highest number of the respondents which, if they stated that they cooperated with other companies the most, they did not state the Chamber of Commerce as an alternative. It is to be highlighted that the companies which participated in the respective research, among all entities on the market, they cooperated the most with other enterprises and cooperated the least with development agencies.

Analyzing how companies develop their innovations, the highest number of them developed innovations individually, without even considering other options. The highest number of them affirmatively answered that they introduced product/service innovation, but it was a novelty only to their company, not to the market they operate on. This is adequate to the results of some other researches in which are presented that SMEs in developing countries are basically oriented to improve internal processes and incremental innovations.

Every company must find its own set of factors, indicators and measures in the process of measuring innovative activities. The most important thing is to pursue innovative orientation and to continuously improve its innovative activities.

\section{CONCLUSION}

The aim of the research was to test the applied questionnaire, as the determination of the possibilities of applying the selected factors/measures in the process of measuring SME innovative activities in the Republic of Serbia. It is certain that there are improvement potentials above all, in the increase in the number of enterprises within the sample; application of the questionnaire to other emerging markets from the region, etc. It is presumable that the majority of companies in such countries have the role of a follower, and much rarer the role of a leader in terms of innovation, since they aim at investing their funds mostly in the purchase of equipment to efficiently follow core activities developed elsewhere (as indicated by performance groups division of Innovation European Scoreboard). This could be tested in future research by expanding geographical research domain.

Measurement of innovative activities at a company could have a positive effect to other company performances and operation, and identification of critical 
factors may be a basis for company innovation strategy creation. There are no officially adopted methods for measuring innovative activities in the Republic of Serbia though there are particular methods/tools (Innovate, Improve, Balanced Scorecard, etc.) which may be used with the aim of getting particular picture about current company situation in terms of innovation.

In this paper we presented the current innovation performance indicators questionnaire used by the Statistical Office of the Republic of Serbia and suggested several improvements that were tested on our SMEs sample. Based on the research results, we got insight into specific innovation activities SMEs perform, as well as key innovation performance indicators SMEs use.

As results from the research show, most of the companies are capable to introduce some kind of innovations - the problem is that in most of the cases, they are not new to market - they are new for the company itself. Most of the companies in developing countries are imitators - not leaders in innovations. Thus, most of the innovative activities are oriented toward equipment purchase, including software, and purchase of other forms of knowledge (intellectual property rights).

Future research directions include more detailed customization of the questionnaire that will capture detailed overview of innovation activities in SMEs. The relationship of public innovation intermediaries and private sector could be tested in order to understand the quality of innovation policies. It will be interesting to expand the research by including more SMEs from various developing countries.

\section{Acknowledgement}

The authors acknowledge the financial support of the Ministry of Education, Science and Technological Development of the Republic of Serbia, within Project No 47005 .

\section{REFERENCES}

[1] Stam, E. \& van Stel, A. (2009). Types of Entrepreneurship and Economic Growth. MERIT Working Papers 049, United Nations University - Maastricht Economic and Social Research Institute on Innovation and Technology (MERIT).

[2] Naudé, W., Szirmai, A., \& Goedhuys, M. (2011). Innovation and Entrepreneurship in Developing Countries. Policy Brief, No. 1, United Nations University, ISBN 978-92-8083093-4.

[3] Teece, D. J., Pisano, G., \& Shuen, A. (1997). Dynamic capabilities and strategic management. Strategic Management Journal, 18, 509-533. https://doi.org/10.1002/(SICI)1097-0266(199708)18:7<509::AIDSMJ882>3.0.CO;2-Z

[4] Short, J. C., Ketchen, D. J., Palmer, T. B., \& Hult, G. T. (2007). Firm, strategic group, and industry influences on performance. Strategic Management Journal, 28, 147-167. https://doi.org/10.1002/smi.574

[5] Newbert, S. (2007). Empirical research on the resourcebased view of the firm: An assessment and suggestions for future research. Strategic Management Journal, 28, 121146. https://doi.org/10.1002/smj.573

[6] Hamel, G. (2000). Leading the Revolution. Harvard Business School Press, Boston, MA
[7] Porter, M. (1996). Competitive Strategy: Techniques for Analyzing Industries and Competitors. $1^{\text {st }}$ Ed., ISBN-10: 0684841487, ISBN-13: 978-0684841489

[8] OECD, (2005). Oslo Manuel - The Measurement of Scientific and Technological Activities. Paris, $3^{\text {rd }}$ Ed., 89117.

[9] Garengo, P., Biazzo, S., \& Bitici, U. S. (2005), Performance measurement systems in SMEs: a review for a research agenda. International Journal of Management Reviews, 7(1), 25-47. https://doi.org/10.1111/j.1468-2370.2005.00105.x

[10] Marques, C. S. \& Ferreira, J. (2009). SME Innovative Capacity, Competitive Advantage and Performance in a 'Traditional' Industrial Region of Portugal. Journal of Technology Management \& Innovation, 4(4), 53-68. https://doi.org/10.4067/S0718-27242009000400005

[11] Radas, S. \& Bozic, L. (2009). The antecedents of SME innovativeness in an emerging transition economy. Technovation, 29, 438-450. https://doi.org/10.1016/j.technovation.2008.12.002

[12] Subrahmanya, M. H. B. (2011). Technological Innovations and Firm Performance of Manufacturing SMEs: Determinants and Outcomes, ASCI Journal of Management, 41(1), 109-122

[13] Schwab, K. (2017). The Global Competitiveness Report 2016-2017, Full Data Edition, Geneva, World Economic Forum.

[14] Aubert, J. E. (2005). Promoting innovation in developing countries: a conceptual framework, World Bank Institute, World Bank Policy Research Working Paper 3554.

[15] Hobday, M. (2005). Firm-level Innovation Models: Perspectives on Research in Developed and Developing Countries, Technology Analysis \& Strategic Management, 17(2), 121-146. https://doi.org/10.1080=09537320500088666

[16] Hewitt-Dundas, N. (2006). Resource and Capability Constraints to Innovation in Small and Large Plants. Small Business Economics, 26(3), 257-277. https://doi.org/10.1007/s11187-005-2140-3

[17] Cohen, W. M. (1995). Empirical studies of innovative activity. Handbook of the Economics of Innovation and Technological Change. Ed P. Stoneman. Oxford: Blackwell, 182-264.

[18] Zacarías, M. A. V. \& Arjona, A. L. L. (2015). Impact of the association capability on innovation in SMEs from developing countries, Revista Vinculategica, 1(1), 786-805.

[19] Tidd, J., Bessant, J., \& Pavitt, K. (2014). Managing Innovation: Integrating technological, market and organizational change, Wiley and Sons, $5^{\text {th }}$ Ed.

[20] Trott, P. (2011). Innovation Management and New Product Development. Financial Times / Prentice Hall; $5^{\text {th }}$ Ed., ISBN10: 0273736566, ISBN-13: 978-0273736561

[21] Hult, G. T. M., Hurley, R. F., \& Knight, G. A. (2004). Innovativeness: Its antecedents and impact on business performance. Industrial Marketing Management, 33(5), 429438. https://doi.org/10.1016/j.indmarman.2003.08.015

[22] Ramaswami, S. N., Srivastava, R. K., \& Bhargava, M. (2009). Market-based capabilities and financial performance of firms: insights into marketing's contribution to firm value. Journal of the Academy of Marketing Science, 37, 97-116. https://doi.org/10.1007/s11747-008-0120-2

[23] Freel, M. S. (2000). Do Small innovating firms outperform noninnovators? Small Business Economics, 14(3), 195-210. https://doi.org/10.1023/A:1008100206266

[24] Gerorski, P. A. \& Machin, S. (1992). Do innovating firms outperform non-innovators? Business Strategy Review, 3(2), 79-90. https://doi.org/10.1111/j.1467-8616.1992. tb00030.x

[25] Gongming, Qian \& Lee, Li (2003). Profitability of small and medium-sized enterprises in high-tech industries: The case for biotechnology industry. Strategic Management Journal, 24, 881-887. https://doi.org/10.1002/smj.344 
[26] Verhees, F. J. H. M. \& Meulenberg, M. T. G. (2004). Market orientation, innovativeness, product innovation, and performance in small firms. Journal of Small Business Management, 42(2), 134-154. https://doi.org/10.1111/j.1540-627X.2004.00102.x

[27] Storey, D. (1994). Understanding the Small Business, Sector. London: Routledge.

[28] Welsh, J. A. \& White, J. F. (1981). Converging on characteristics of entrepreneurs, Frontiers of Entrepreneurship Research, 504-515.

[29] Vujović, A., Jovanović, J., Krivokapić, Y., Peković, S., Soković, M., \& Kramar, D. (2017). The relationship between innovations and quality management system, Technical Gazette, 24(2), 551-556. https://doi.org/10.17559/TV-20150528100824

[30] Chennell, A., Dransfield, S., Field, J., Fisher, N., Saunders, I., \& Shaw, D. (2000). OPM: a system for organisational performance measurement. Proceedings of the Performance Measurement - Past, Present and Future Conference, Cambridge, 19-21 July. https://doi.org/10.1111/j.1468-2370.2005.00105.x

[31] Frascati Manual, 2002, OECD, Publications Service, 2, France.

[32] Mosurović Ružičić, M. (2012). Organizacije i inovacije, monografija, Beograd.

[33] Wu, J. (2007). Company innovativeness measurement Development of an assessment tool to measure the innovation performance of companies. Technology, Policy and Management, Technology, Strategy \& Entrepreneurship (TSE), Delft University of Technology.

[34] Sepúlveda, J. \& Vasquez, E. (2014). Multicriteria Analysis for Improving the Innovation Capability in Small and Medium Enterprises in Emerging Countries. American Journal of Industrial and Business Management, 4, 199-208. https://doi.org/10.4236/ajibm.2014.44027

[35] Statistical Yearbook of the Republic of Serbia 2017 Science and Culture

[36] Avlonitis, G. J., Kouremenos, A., \& Tzokas, N. (1994). Assessing the Innovativeness of Organizations and its Antecedents: Project Innovstrat. European Journal of Marketing, 28(11), 5-28. https://doi.org/10.1108/ 03090569410075812

[37] North, D. \& Smallbone, D. (2000). The Innovativeness and Growth of Rural SMEs during the 1990s. Regional Studies. 34(2), 145-157. https://doi.org/10.1080/ 00343400050006069

[38] Wang, C. L. \& Pervaiz, K. A. (2004) The Development and Validation of the Organisational Innovativeness Construct using Confirmatory Factor Analysis. European Journal of Innovation Management, 7(4), 303-313. https://doi.org/10.1108/14601060410565056

[39] Kleinknecht, A., van Montfort, K., \& Brouwer, E. (2002). The Non-trivial Choice between Innovation Indicators. Economics of Innovation and New Technology, 11(2), 109. 121. https://doi.org/10.1080/10438590210899

[40] The CIS Harmonised Survey Questionnaire, The Fourth Community Innovation Survey (CIS IV), December 2017

[41] Borocki, J., Cvijic, M., \& Vekic, A. (2017). Evaluation of innovative activities of SMEs in emerging markets: example from Republic of Serbia. XVII International Scientific Conference on Industrial Systems (IS'17) Novi Sad, Serbia, October 4. - 6. 2017. University of Novi Sad, Faculty of Technical Sciences, Department for Industrial Engineering and Management Available online at http://www.iim.ftn.uns.ac.rs/is17

[42] Zahra, S. A., \& Covin, J. G. (1995). Contextual influences on the corporate entrepreneurship-performance relationship: A longitudinal analysis. Journal of Business Venturing, 10(1), 43-58. https://doi.org/10.1016/0883-9026(94)00004-E
[43] Zahra, S. A. (1993). Environment, corporate entrepreneurship, and financial performance: A taxonomic approach. Journal of Business Venturing, 8(4), 319-340. https://doi.org/10.1016/0883-9026(93)90003-N.

[44] Griffin, A. \& Page, A. L. (1996). PDMA success measurement project: Recommended measures for product development success and failure. Journal of Product Innovation Management, 13(6), 478-496. https://doi.org/10.1016/S0737-6782(96)00052-5

[45] Sheskin, D.J. (2011) Handbook of Parametric and NonParametric Statistical Procedures. $5^{\text {th }}$ Edition, Chapman \& Hall/CRC, London. ISBN 978143985801

\section{Contact information:}

Indira POPADIĆ, PhD Candidate

University of Belgrade, Technical Faculty Bor,

12 Vojske Jugoslavije, 19210 Bor, Republic of Serbia

indirapopadic@gmail.com

Jelena BOROCKI, Associate Professor

University of Novi Sad, Faculty of Technical Sciences

Trg Dositeja Obradovića 6, 21000 Novi Sad, Republic of Serbia

borocki@uns.ac.rs

Mladen RADIŠIĆ, Associate Professor

University of Novi Sad, Faculty of Technical Sciences

Trg Dositeja Obradovića 6, 21000 Novi Sad, Republic of Serbia

mladenr@uns.ac.rs

Ivan ŠTEFANIĆ, Full Professor

Josip Juraj Strossmayer University of Osijek

TERA TEHNOPOLIS d.o.o.

Gajev trg 6, HR-31000 Osijek, Croatia

stefanic@tera.hr

Lena DUSPARA, PhD, senior lecturer

College of Slavonski Brod

Dr. Mile Budaka 1, 35000 Slavonski Brod, Croatia

lena.duspara@vusb.hr 